Michaela Faltýnková

\title{
ANALÝZA PROSTOROVÝCH SLOVES S INKORPORACÍ LOKATIVNÍCH ARGUMENTU゚ V ČEŠTINĚ ${ }^{1}$
}

\author{
ON LOCATION AND LOCATUM VERBS IN CZECH
}

\begin{abstract}
This paper investigates a class of Czech denominal spatial verbs, which are formed by incorporation. Examples include verbs such as ustájit (koně) 'to put a horse in the stable, lit. to stable a horse', vytapetovat (pokoj) 'to decorate the room with wallpaper, lit. to wallpare the room'. The goal is to characterize the verbs by means of the cognitively-semantic notions of Figure and Ground. I show that these notions create a bifurcation of such verbs into two classes depending on which category the incorporated noun belongs to. The collected data are classified further by a number of tests.
\end{abstract}

\section{KEYWORDS}

spatial verbs; incorporation; Figure; Ground; argument structure; thematic roles

\section{1 Úvod}

Prostorová slovesa, která stojí v ústředním zájmu této studie, jsou výsledkem derivačního procesu zvaného inkorporace. O teorii inkorporace, která popisuje změny ve valenční struktuře sloves, obohatil transformační generativní gramatiku Mark C. Baker (1988). Jedná se o proces, kdy se sémanticky nezávislé slovo stane základem jiného slova (BAKER 1988, 10). Př́kladem českého prostorového slovesa s inkorporací mohou být verba ustájit (koně) či vytapetovat (pokoj).

1 Na prvním místě musím vyjádřit poděkování Pavlu Cahovi, a to za podnětné diskuze o tomto tématu, stylistické korektury textu a za jeho nakažlivé, neutuchající nadšení pro řešení sebezapeklitějšího lingvistického problému. Děkuji také recenzentům za jejich připomínky. 
Slovesa tohoto typu se dají klasifikovat do dvou skupin, a to podle toho, který prostorový argument je jménem inkorporovaným ve slovese vyjádřen. Tyto prostorové argumenty budu charakterizovat termíny Figure (F) a Ground (G). Jedná se o kognitivně-sémantické kategorie, navržené Talmym (2000), které určujíl lokaci v prostoru. ${ }^{2}$ Figure označuje neznámou entitu, která je umistována s ohledem na druhou entitu, tj. Ground. Ta je známou, umístěnou entitou, sloužící jako referenční předmět pro lokaci Figure (TALMY 2000). Př́́kladem této dichotomie může být věta Petrovo kolo (F) leží blízko Mariina domu (G). Lokace Petrova kola (Figure) je určena podle dobře známé budovy, jíž je Mariin dům (Ground).

Tyto kognitivně-sémantické kategorie nemusí být reprezentovány pouze rozvitými jmennými frázemi (jako $\mathrm{v}$ dané větě o něco výše), ale mohou být vyjádřeny také např. kořenem slovesa (TALMY 2000, 335-336). To je př́ípad cílových sloves této práce. Podívejme se na věty v př́íladu (1).

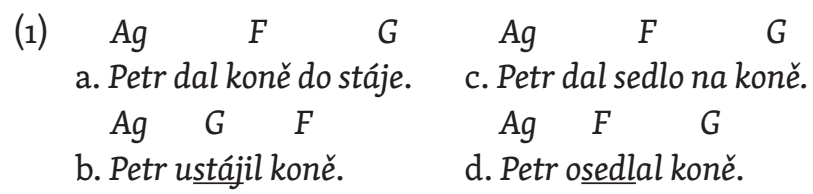

Věty (1a) a (1c) jsou jednoduché věty vyjadřující agentem (Ag) zapř́činěný pohyb jedné entity (Figure, F) na určité místo (Ground, G). Pod nimi jsou k nim příslušné sémanticky identické věty (1b) a (1d). Ty obsahují predikát, kde je jeden z lokativních argumentů inkorporován (vyjádřen kořenem slovesa).

Na první pohled zde může vyvstat problém ohledně sémantické identity těchto parafrází. Konkrétně se jedná o otázku, zda z věty Petr dal sedlo na koně skutečně vyplývá, že Petr osedlal koně, anebo je tato parafráze nepřesná, protože Petr mohl sedlo na koně pouze položit. Abychom na tuto otázku odpověděli, nechme slunce na chvíli popojít za hranice češtiny a posvitme si na fenomén, rozšířený např́ič jazyky, kde dochází $k$ vypouštění členů před substantivy v předložkových (zvláště lokativních) frázích, např̀. injail ,ve vězení. De Swart a Zwarts (2009) označují substantiva bez členu jako holé singuláry, které porovnávají s jejich "plnými“ (dále příznakovými) protějšky, v tomto př́ípadě in the jail. Pozorováním těchto minimálních párů dochází k zajímavému zjištění: Holé singuláry odpovídají prototypickému významu předložkové fráze, tedy „in jail“ odpovídá významu „uvězněný“. Příznakové singu-

2 L. Talmy tyto termíny převzal z oblasti psychologie, kde souvisí s organizací percepčního pole. Svět kolem nás vnímáme tak, že se soustředíme na jednu část vjemového pole, které tvoří Figure (figuru), neboli předmět vnímání. Figura je výrazná, jasně zřetelná a ohraničená. Všechny ostatní předměty tvoří Ground (pozadí), které nevnímáme zcela zřetelně. Například stojíme-li na zámeckém nádvoří $\mathrm{s}$ kašnou, kterou pozorujeme, bude pro nás tento předmět figura a vše ostatní pozadí. Figura ale může být i předmět prostorově vzdálený, např. jestliže z rozhledny pozoruju věž kostela nějaké vesnice, bude pro mě figurou tato věž v dáli a všechny ostatní, i bližší předměty, se stanou pozadím. Vztah figury a pozadí jako první popsal dánský psycholog Edgar Rubin (PLHÁková 2004, 133). 
láry jsou užívány $\mathrm{k}$ vyjádření netypického významu této fráze, čili „in the jail“ je užito za účelem popisu lokace dané osoby, ta ale nemusí být nutně vězněná, může být ve věznici pouze na návštěvě (De SWART - ZwARTS 2009, 285). Distinkce mezi holými a př́znakovými singuláry nám pomůže rozřešit otázku ohledně významové identity mezi parafrázemi v (1). Inkorporovaný lokativní argument odpovídá tzv. holému singuláru a povoluje pouze prototypické čtení. $Z$ věty Petr osedlal koně nutně vyplývá, že Petr dal sedlo na koně řádným způsobem. Věta Petr dal sedlo na koně povoluje obě čtení (prototypické i volnější), a v důsledku nám neříká nic víc, než že sedlo se nachází na koni (jakýmkoli způsobem). Parafráze mezi (1b) a (1d) je tedy přesná, pokud čteme (1d) ve smyslu holého singuláru. Potenciální významové rozdíly mezi (1b) a (1d), stejně jako mezi (1a) a (1c), jsou důsledkem faktu, že věty $(1 \mathrm{a}, \mathrm{c})$ povolují navíc i interpretaci př́íznakového singuláru. ${ }^{3}$

Tato synonymie mezi relevantním významem $(1 b, d)$ a jejich parafrázemi $(1 a, c)$ je východiskem pro teorii inkorporace (BAKER, 1988). Tato teorie zachycuje paralelní význam tak, že předpokládá pro obě dvojice vět v (1) stejnou hloubkovou strukturu. Rozdíl jejich povrchových struktur je způsoben právě procesem inkorporace, kdy jeden $\mathrm{z}$ argumentů slovesa se pomocí posunu hlavy stane základem samotného predikátu. ${ }^{4}$ Svou syntaktickou suverenitu si však inkorporovaný výraz zachovává, což dokazuje fakt, že je schopen prosadit se v argumentové struktuře slovesa a stáhnout si pro sebe, respektive obdržet od slovesa, tematickou roli. ${ }^{5} \mathrm{~V}$ př́padě prostorových sloves jsou ve hře dvě tematické role, jež může argument slovesa obdržet. Jednou z nich je téma (odpovídající kognitivně-sémantické kategorii Figure) a druhou je lokace (odpovídající kategorii Ground). Na základě těchto dvou druhů lokativního argumentu je možné vydělit dvě třídy sloves s nominální inkorporací. Podle Eve Clarkové a Herberta Clarka je budu nazývat locatum verbs a location verbs (CLARK - CLARK, 1979). ${ }^{6}$

Třída locatum verbs zahrnuje slovesa typu osedlat (koně), jako je v př́íladu (1d). Kořen sloves typu osedlat (koně) vyjadřuje lokativní argument Figure (přemístovaný objekt), přímý objekt slovesa vyjadřuje jeho koncové umístění. Třída location verbs zahrnuje slovesa typu ustájit (koně), jak ukazuje věta (1b). Kořen sloves typu ustájit (koně) vyjadřuje inkorporovaný lokativní argument Ground (konečné umístění nějaké entity), umístovaná entita se nachází v pozici přímého objektu (MATEU, 2001).

Cílem mého př́spěvku je představit vzorové př́íklady sloves s inkorporací, jaké jsou ve větách (1b) a (1d), tato slovesa podrobit empirickým testům (sekce 2) a dále

\footnotetext{
3 Za upozornění na tuto analogii děkuji Pavlu Cahovi.

$4 \quad$ V originální literatuře se jedná o posun hlavy, analýze však nezpůsobí žádný problém realizovat dosažení cílového stavu struktury posunem fráze. Za tuto připomínku děkuji Guido Vanden Wyngaerd (p.c.).

5 Ačkoliv tuto tematickou roli nikdy nesaturuje zcela, o tom viz dále.

6 Dále tyto třídy sloves diskutovali např́íklad HALE - KEYSER (1993, 2002), KIPARSKy (1997), BLEOTU (2014) a další.
} 
utřídit a ukázat reprezentativní seznam sloves s inkorporací lokativních argumentů v českém jazyce (sekce 3 a 4).

\section{Inkorporace Figure versus inkorporace Ground}

Dělba sloves do dvou tř́́d podle typu inkorporovaného argumentu nabývá na zajímavosti díky slovesu rámovat (obraz).

Toto sloveso dovoluje užití ve dvou různých kontextech, přičemž každý z nich odpovídá jinému typu interpretace. A. Petr si koupil obraz a vložil ho do předem připraveného rámu (viz 2a). B. Petr vytáhl z půdy rám, který oprášil a připevnil kolem obrazu. Na první pohled se tedy toto sloveso zdá být dvojznačným, umožňujícím jak inkorporaci argumentu Figure (2b), tak inkorporaci Ground (2a), nebot je možné užít ho v obou kontextech, A i B.?

\section{(2) a. Petr dal obraz (F) do rámu (G). \\ b. Petr dal rám (F) na obraz (G).}

Z obecného hlediska popisu těchto konstrukcí zde vyvstává otázka klasifikace. Sloveso rámovat vypadá $\mathrm{z}$ hlediska svého kognitivního významu jako sloveso, které lze zařadit jak do kategorie location verbs, tak do kategorie locatum verbs. Otázkou ale je, zda této dvojí možné klasifikaci odpovídá i jeho gramatické chování. Ne všechny situace, kdy vyjadřujeme kategorie Figure a Ground, totiž můžeme realizovat strukturou s inkorporací. Např. větu Petr dal na stůl $(G)$ večeři $(F)$ nelze parafrázovat jako *Petr (na-)stolil večeři. Je tedy teoreticky možné, že v gramatice vede k inkorporaci pouze jedna ze dvou možných významových struktur ve (2), a sloveso rámovat tedy z gramatického hlediska dvojznačné není.

Potřebujeme tedy najít nějaký nezávislý test (kromě parafráze), který bude jasně diferencovat tř́dy locatum verbs a location verbs v českém jazyce, aby bylo možné říci, zda dvojznačnost slovesa rámovat je skutečná, či zdánlivá.

\subsection{Konstrukce s hyponymnim objektem}

Testem, který nám pomůže gramatické vlastnosti diagnostikovat, je chování prostorových sloves v konstrukci s hyponymním objektem (hyponymous argument construction, viz HALE - KeYSER 2002, 71). Hyponymní objekt je jméno nebo jmenná fráze plnící gramatickou funkci předmětu, které inkorporované jméno více specifikuje, je mu významově podřazeno. Věta (3a) obsahuje objekt se stejným kořenem

$7 \quad$ V angličtině je dvojí interpretace jednoho slovesa běžným jevem. Např. 1. He shelved (G) the books (F) (doslova „Napolicoval knihy“). 2. He shelved (F) the wall (G) (doslova „Opoličkoval zed“'). V prvním př́padě sloveso „shelve“ obsahuje inkorporaci Ground, ve druhé větě má inkorporovaný lokativní argument Figure. 
jako je kořen slovesa (cognate object = př́buzný objekt). Věty (3b) a (3c) obsahují objekt, který určuje (pod)druh jména vyjádřeného v kořeni slovesa, nebo ho více specifikuje (hyponymous object).

(3) a. ?Petr tancuje tanec.

b. Petr tancuje tango.

c. Petr tancuje romantický tanec.

Větné konstrukce s hyponymním objektem nám umožní rozlišit slovesa s inkorporací Figure a Ground. Následující prríklady totiž ukazují, že slovesa s inkorporací Ground (location verbs) vyžadují hyponymní objekt v podobě předložkové fráze (4), zatímco slovesa s inkorporací Figure (locatum verbs) musí nutně mít hyponymní objekt v instrumentálu (5).

(4) a. Ustájili koně v té nejlepši stáji.

b. *Ustájili koně tou nejlepší stájí.

c. Policie uvěznila pachatele do vězení s ostrahou.

d. *Policie uvěznila pachatele vězením s ostrahou.

(5) a. *Nakrémovala si obličej v mandlovém krému.

b. Nakrémovala si obličej mandlovým krémem.

c. *Vytapetovala pokoj v červené tapetě.

d. Vytapetovala pokoj červenou tapetou.

Aplikujeme-li tento test na problémové sloveso rámovat, dostaneme následující výsledek.

(6) a. Petr rámoval obraz do zlatého rámu.

b. Petr rámoval obraz zlatým rámem.

Obě věty jsou v pořádku. $Z$ toho plyne, že sloveso rámovat je skutečně ambigní.

\subsection{Kompatibilita prefixů}

Kromě konstrukcí s hyponymními objekty můžeme ke gramatické desambiguaci location a locatum verbs použít prefixy, které jsou kompatibilní pouze s jednou z těchto slovesných tříd. ${ }^{8}$ Př́klady v (7) ukazují, že prefix o- se zdá být kompatibilním pouze s tř́́dou locatum verbs obsahující inkorporaci Figure.

8 Např. v němčině je většina sloves tohoto typu tvořena prefixací a sufixací (stejně jako v češtině). Pro třídu locatum verbs jsou typickými prefixy ver-a be- (vergolden ,pozlatit', besanden, posypat pískem'), pro tř́du location verbs prefix ein- (eindosen, zakonzervovat', einkellern, uložit do sklepa'), viz KIPARSKY $(1997,9)$. 
(7) a. Inkorporace Figure: osedlat, olemovat, onálepkovat, ošatit, obarvit,... b. Inkorporace Ground: *ogarážovat, *ostájit, *ověznit, *okonzervovat, *oskladnit,...

Kombinací dosud představených testů (hyponymní objekty, prefix o-) vznikne predikce: Pokud se sloveso kombinuje s prefixem o- (což ukazuje na inkorporaci Figure), pak hyponymní objekt musí být vyjádřen instrumentálem. $\mathrm{K}$ důkazu tohoto tvrzení se dobře hodí právě sloveso rámovat, které je v principu strukturně dvojznačné. Připojíme-li k tomuto slovesu prefix za- (8a) / (8b) a prefix o- (8c) / (8d), dostaneme následující výsledky.

(8) a. Petr zarámoval obraz do zlatého rámu.

b. Petr zarámoval obraz zlatým rámem.

c. ??Petr orámoval obraz do zlatého rámu.

d. Petr orámoval obraz zlatým rámem.

Varianty (8a), (8b) a (8d) zní přirozeně, ale věta (8c) ne. To znamená, že prefix o- je nekompatibilní s gramatickou strukturou location verbs (tedy takovou, kde inkorporuje Ground). Stejné výsledky můžeme pozorovat i u pasiva.

(9) a. ??Obrazje orámovaný ve zlatém rámu.

b. Obraz je orámovaný zlatým rámem.

Př́klad (9) tak potvrzuje předchozí závěr, a sice že prefix o- není kompatibilní se slovesy, které inkorporují argument vyjadřující kategorii Ground. Připojení prefixu tedy vede $k$ desambiguaci slovesa "rámovat“ (obraz) a k jeho zařazení do třídy locatum verbs.

Abychom ukázali, jak test funguje, použijeme jej na další potenciálně dvojznačné sloveso s prefixem o-, jako je např. sloveso ohradit (dobytek). Můžeme si položit stejnou otázku jako u předchozího slovesa: Dáváme hrazení kolem dobytka, nebo dobytek do hrazení? Podívejme se na věty v př́íkladu (10).

(10) 9 a. *Petr ohradil dobytek do dřevěného hrazení.

b. Petr ohradil dobytek dřevěným hrazením.

c. ${ }^{*}$ Dobytek je ohrazen $v$ dřevěném hrazení.

d. Dobytek je ohrazen dřevěným hrazením.

Test pomocí větné konstrukce s hyponymním objektem ukazuje, že ohrada plní funkci Figure a dobytek je referenčním předmětem (Ground). Z hlediska grama-

9 V testových větách je použita pohyblivá entita (dobytek) z toho důvodu, že pohyblivé entity mohou být kognitivně interpretovány jako Ground, nebo jako Figure. Použití takovéhoto typu objektu je nezbytným předpokladem $k$ tomu, aby strukturní ambiguita byla vůbec možná. 
tického chování slovesa je tudíž ohrada dávána kolem dobytka. ${ }^{10}$ Tento fakt je plně ve shodě s tím, že toto sloveso má prefix o-. U slovesa ohradit (na rozdíl od rámovat) soudíme, že ačkoliv v zásadě kognitivně umožňuje oba druhy inkorporace, gramaticky se chová jednoznačně (a sice jako locatum verbs).

\section{Location verbs}

$\mathrm{V}$ předcházející sekci byl popsán test rozlišující location verbs a locatum verbs v českém jazyce. Nyní se blíže podíváme na slovesa, která v konstrukci s hyponymním objektem vyžadují předložkovou frázi a mají v sobě inkorporovaný argument Ground. Cílem sekce je tato slovesa dále rozčlenit podle jejich syntaktických a sémantických vlastností.

\section{1 Členění location verbs}

Jako východisko členění použijeme fakt, že lokativní předložkové fráze (ze kterých jsou tato slovesa odvozena) se vyskytují ve dvou základních podobách, a sice statické a dynamické. Slovy Hirschové $(1977,107)$ : „Předložka (jako významová složka předložkového pádu) označuje bud' místo (předložkový pád statický), nebo směr (předložkový pád dynamický). Srov. (stát) v pokoji - (jít) do pokoje." Toto dělení je běžně přijímáno i v současné zahraniční literatuře. Např. Svenonius $(2010,127)$ shrnuje: „A recurring observation is the basic distinction between what can be called Place (associated with locational meanings) and what is often called Path (associated with directed motion)."

Toto dělení na statické a dynamické předložkové fráze koreluje s typem děje, jaký je slovesem vyjadřován. Konkrétně platí, že dynamické předložkové fráze (do lesa) nelze kombinovat se statickými slovesy (zůstal). V této sekci tedy budu dělit location verbs na statická a dynamická slovesa, přičemž toto dělení má oporu v základním rozlišení dvou typů předložkových frází.

Oprávněnost tohoto kritéria je podpořena i tím, že když se podíváme na význam jednotlivých sloves, nalezneme přesně dvě třídy sloves odpovídající tomuto základnímu rozdílu. Jedna třída sloves označuje místo, kde se objekt nachází, a druhá tř́da místo, kam objekt směřuje, vyjadřuje tedy pohyb.

\section{(11) ${ }^{11}$ (i) Slovesa vyjadřující stav - slovesa typu skladovat}

(ii) Slovesa vyjadřující změnu stavu - slovesa typu lahvovat

10 Zde si můžeme všimnout zajímavého rozdílu mezi češtinou a angličtinou. V angličtině patří sloveso ohradit (koně) 'corral the horses' do třídy location verbs (HALE - KEYSER 1993, 55), zatímco test pomocí větné konstrukce s hyponymním objektem ukazuje, že v češtině toto sloveso náleží ke tř́dě locatum verbs. $Z$ toho vyplývá, že jedna z vlastností prefixu o- je ta, že neumožňuje Ground inkorporaci.

11 Příslušnost slovesa do kategorie „vyjadřující stav“ a „vyjadřující změnu stavu“ můžeme testovat následujícím způsobem: Je-li sloveso modifikovatelné adverbiem, vyjadřuje změnu stavu, např. Petr lahvoval víno rychle. Není-li modifikovatelné adverbiem, vyjadřuje stav, např. *Petr skladoval mléko rychle. 
K automatickému rozlišení těchto dvou tříd je možné vytvořit tzv. „v/do-test“ rozdělující location verbs do těchto dvou kategorií. Předpokládám spolu s Kiparskym (1997, 7-8), že inkorporované jméno nikdy zcela nenasytí danou tematickou roli, a proto je vždy možné přidat do věty syntaktický výraz korespondující s inkorporovaným výrazem (tj. hyponymní objekt). Použijeme-li typickou předložku pro vyjádření statického pádu $v$ a klasickou předložku pro vyjádření dynamického pádu do, dostaneme následující výsledky.
(12) a. skladovat jablka ve skladè/*do skladu
b. lahvovat víno *v láhvi/do láhve

Tyto příklady ukazují, že neprefigovaná slovesa stavová přijímají pouze předložku vyjadřující předložkový pád statický - $v$, a slovesa změny stavu zase jen předložku vyjadřující předložkový pád dynamický - do. Navíc platí, že mezi stavovými prostorovými slovesy s inkorporací se nevyskytují žádné prefigované výrazy. ${ }^{12}$

U některých prefigovaných sloves vyjadřujících změnu stavu se však vyskytují jak lokativní ( $v$ tak směrové (do) předložkové fráze, viz (13).
(13) a. Uvěznit pachatele ve vězení/do vězení.
b. Ubytovat nájemníky v bytě/do bytu.
c. Uskladnit jablka ve skladě/do skladu.
d. Ustájit konè ve stáji/do stáje.

Je to důvod domnívat se, že tento test je špatný? Nikoliv. Pořád totiž platí, že předložka do je možná pouze u sloves změny stavu. Nicméně vidíme, že slovesa změny stavu jsou dvojího typu: neprefigovaná, kde je možná pouze předložka do (jako ve (12)), a slovesa prefigovaná, kde u některých lze použít jak do, tak $v$.

O slovesech s prefixem dále nezávisle platí, že (přinejmenším některá) jsou schopna vynutit směrovou interpretaci stavových předložkových frází. Jako příklad si můžeme uvést předložku vedle. Tato předložka má s neprefigovanými slovesy většinou stavovou interpretaci: stál vedle mě. Pokud je sloveso prefigováno, mohou takové stavové předložky získat směrovou interpretaci a vyjádřit cíl pohybu: prì-stál vedle mě. ${ }^{13}$

\footnotetext{
12 Anonymní recenzent zmiňuje existenci prefigovaných stavových sloves jako sousedit, náležet. Tato slovesa však nejsou inkorporační. Viz rovněž CAHA - ZıKovÁ (2016) pro diskusi specifických vlastností takovýchto sloves.

13 O tom, jak se slovesa podílejí na vyjadřování cíle pohybu, existuje značně obsáhlá literatura. Pro zajímavou diskuzi $\mathrm{k}$ tomuto tématu v češtině viz MEDová - TARALDSEN (2007). Ohledně prefixace ve slovanských jazycích obecně viz Biskup (2015).
} 
Konečné členění sloves s inkorporací Ground tak vypadá následovně:

(14) (i) Slovesa vyjadřující stav - typ skladovat $($ jenom $v)$ (ii.a) Slovesa vyjadřující změnu stavu - s prefixem, typ uskladnit $\quad(v$ i do) (ii.b) Slovesa vyjadřující změnu stavu - bez prefixu, typ lahvovat (jenom do)

\subsection{Seznam sloves s inkorporací Ground ${ }^{14}$}

Na závěr představujeme vybraný vzorek sloves s inkorporací lokativního argumentu Ground.

\section{Slovesa (i) vyjadřující statickou lokaci:}

Archivovat (dokumenty), garážovat (motorku), konzervovat (materiál vlaboratoři), skladovat (mléko ve sklenicích), věznit (zločince), žalářvvat (politicky nespolehlivé osoby).

\section{Slovesa (ii.a) vyjadřující provedenou změnu lokace:}

Zagarážovat (motorku), zaarchivovat (dokumenty), ubytovat (se v hotelu), uvěznit (zločince), ustájit (koně), uskladnit (brambory a zeleninu), zaškatulkovat (druhé do kategorií), zakonzervovat (materiál v laboratoři), nalodit (zboži na plachetnici), natankovat (palivo), nalahvovat (víno), nabalíkovat (slámu), napytlovat (mouku).

\section{Slovesa (ii.b) vyjadřující probíhající změnu lokace:}

Balíkovat (slámu), lahvovat (víno), pytlovat (zeleninu/mouku), sáčkovat (výplaty), rádkovat (brambory), škatulkovat (druhé do kategorií).

\section{Locatum verbs}

Do této skupiny patři slovesa, která $\mathrm{v}$ hyponymous argument construction vyžadují hyponymní objekt $\mathrm{v}$ instrumentálu a v kořeni mají inkorporovaný argument Figure. Ve srovnání se skupinou sloves s inkorporací Ground je tato třída mnohem početnější a pro české mluvčí více přirozená. ${ }^{15}$ Nemusíme se v tomto případě potýkat s otázkou, jak vzájemně odlišit výrazy vyjadřující stav od výrazů vyjadřujících změnu stavu, protože locatum verbs mohou ze své vlastní podstaty reflektovat pouze změnu stavu. Figure, Talmym definované jako umíst'ovaná entita, bude vždy objektem měnícím svou polohu/stav. S čím se však, na rozdíl od druhé třídy sloves, budeme muset vypořádat, je, jak odlišit slovesa s inkorporací lokativního argumentu od sloves s inkorporací instrumentu/nástroje.

14 Kontext užití těchto sloves uvedený v závorkách pochází z reprezentativního korpusu psané češtiny SYN2O15 nebo z www.google.cz.

15 Slovesa s inkorporací Figure mají mnohem vyšší frekvenci užití než slovesa s inkorporací Ground. Viz reprezentativní korpus psané češtiny SYN2015. 


\subsection{Souboj tematických rolí - téma versus instrument}

Slovesa patřící do třídy locatum verbs obsahují jako inkorporovaný argument téma: tedy objekt, který v průběhu děje mění své umístění v prostoru. U sloves jako tapetovat (zed') či osedlat (koně) nepochybujeme, že patří do právě diskutované skupiny (tapety nebyly na zdi $\rightarrow$ jako výsledek děje na zdi jsou). Stejně tak můžeme u určitých sloves s poměrnou jistotou tvrdit, že kořen daného slovesa odpovídá substantivu s rolí nástroje, např. válc-ovat něco. Avšak co se slovesy jako stmelit, zatmelit, sešroubovat? Je tmel ve větě Petr zatmelil prasklinu tématem, či nástrojem?

Pojd'me si velmi stručně oba pojmy představit. Tematická role téma je přidělena tomu argumentu slovesa, který je zasažen dějem a podstoupí změnu lokace. Instrument je jako tematická role přidělena argumentu označujícímu nástroj k provádění děje (GREPL - KARík 1998, 39). Znalost těchto definic nám však v rozřešení dané situace př́liš nepomůže, protože se zdá, že např. slovesu tmelit lze konceptuálně rozumět oběma způsoby. Tmel může být jednak nástroj, pomocí kterého dosáhneme kýženého stavu (stůl drží pohromadě), stejně tak může být i něčím, co dáme na stůl s tím výsledkem, že stůl drží pohromadě. Proto je třeba najít nějaký způsob, jak diferencovat slovesa s inkorporací tématu a instrumentu.

Hale a Keyser $(1993,91)$ charakterizují location verbs jako putting verbs (umístovací slovesa), která sdílí všechny základní vlastnosti se slovesem put (dát ve významu ,umístit'). My dále zastáváme názor, že základní vlastnosti se slovesem dát nesdílí jen location verbs, ale také locatum verbs (která podle Halea a Keysera sdílí základní vlastnosti se slovesem provide ,opatřit'). Parafrázujeme-li větu Marie osedlala koně (která obsahuje predikát zahrnující inkorporované téma) pomocí slovesa dát, dostaneme významově identickou větu Marie dala sedlo na koně. Užijeme-li stejný způsob parafráze u věty Marie vykartáčovala koně (která obsahuje predikát zahrnující inkorporovaný instrument), dostaneme větu Marie dala kartáč na koně, jež s první větou sémanticky nekoresponduje. Viz př́íklad (15).

(15) a. Marie osedlala koně = Marie dala sedlo na koně.

b. Marie vykartáčovala koně $\neq$ Marie dala kartáč na koně.

Tento test nám tedy ř́ká, že věty, jejichž predikáty jsou slovesa s inkorporací instrumentu, nelze parafrázovat pomocí slovesa dát tak, aby hrubý význam sdělení zůstal zachován. Aplikujeme-li test parafráze na nejistá slovesa, dostaneme následující výsledky:

(16) a. Petr stmelil vázu $\neq$ Petr dal tmel na vázu.

b. Karel zatmelil praskliny = Karel dal tmel na praskliny.

c. Josef sešrouboval stůl $\neq$ Josef dal šroub na stůl.

Pokud je tento test správný, slovesa stmelit a sešroubovat ve větách (16a) a (16c) 
nemohou obsahovat inkorporovaný argument téma, musí se nutně jednat o instrument. Sloveso zatmelit ve větě (16b) naopak mezi slovesa s inkorporací argumentu téma patří. Do jisté míry je tento výsledek podobný výsledku toho testu, který byl užit k rozlišení sloves s inkorporací Figure a Ground. I tam jsme zjistili, že určitá slovesa mohou být víceznačná (rámovat, zde tmelit), a dále že prefixace určitými prefixy mohou slovesa jednoznačně zařadit do určité tř́́dy.

Př́klad (16) také ukazuje jistou problematičnost v možnosti prefigovat locatum verbs prefixem $s$-. Protože se mezi dalšími výrazy v této tř́iě ani ve tř́dě location verbs žádná slovesa s tímto prefixem nevyskytují, považuji ho za nekompatibilní s prostorovými slovesy s inkorporací lokativního argumentu. Tento prefix je naopak kompatibilnís významem nástroje.

\section{2 Členění locatum verbs}

Po vyloučení sloves s inkorporovaným instrumentem se vratme k vnitřní diferenciaci locatum verbs. Jak již bylo řečeno v úvodu kapitoly, slovesa této třídy vyjadřují pouze změnu stavu. Ta může být bud' ukončená (provedená změna stavu, slovesa jsou dokonavá), nebo trvající (prováděná změna stavu, slovesa jsou nedokonavá). Do druhé skupiny (i.b) patří neprefigovaná slovesa, s prefixem se objeví pouze sekundární imperfektiva (př. osedlávat) ${ }^{16}$. V první skupině (i.a) jsou slovesa s různými druhy prefixů, proto budu tuto subkategorii z důvodu přehlednosti ještě dále diferencovat dle typu prefixu na další podskupiny. Spolu s Romanovou $(2006,63)$ se přikláníme $k$ názoru, že prefix výrazně modifikuje význam slovesa a tvoří „nové slovo", proto počítáme každé prefigované sloveso jako samostatný výraz. Členění locatum verbs:

(17) (i.a) slovesa vyjadřující změnu stavu - dokonavá, typ vytapetovat
(i.b) slovesa vyjadřující změnu stavu - nedokonavá, typ tapetovat

\subsection{Seznam sloves s inkorporací Figure ${ }^{17}$}

Vybraný vzorek sloves s inkorporací lokativního argumentu Figure.

\section{Slovesa (i.a) vyjadřující provedenou změnu lokace:}

A: s prefixem o-: olemovat (budovu vlajkami), onálepkovat (autobusy/někoho néčm), ozbrojit (armádu), ošatit (dítě), obarvit (vlasy), osedlat (koně).

B: s prefixem za-: zasádrovat (končetiny), zavápnit (pozemky), zalakovat (škrábance na autě), zapudrovat (modřiny), zabetonovat (strop), zaštěrkovat (koleje), zavoskovat (láhev), zatmelit (praskliny), zabandážovat (ránu), zamřrízovat (balkon), zazátkovat (láhev).

16 Tyto formy však v článku diskutovány nejsou, proto v přehledu chybí.

17 Kontext užití těchto sloves uvedený v závorkách pochází z reprezentativního korpusu psané češtiny SYN2015, z www.google.cz nebo z http://prirucka.ujc.cas.cz/. 
C: s prefixem na-: naolejovat (panty dveři), nagelovat (si vlasy), nalakovat (si nehty), napudrovat (si tvár)), nakrémovat (boty), naroubovat (stromy), navoskovat (taneční sál). D: s prefixem pře-: ve významu „přiliš": převápnit (půdu), préesolit (polévku), prèeprřit (pokrm), ve významu „znovu“: preolejovat (podlahu), prelakovat (si nehty), přepudrovat (tvár), prekrémovat (boty), preroubovat (větve stromu).

E: s prefixem po-: pohliníkovat (výfuk od auta), pobronzovat (kašnu), pochromovat (kolíky), pocínovat (plech), poniklovat (chladič), pozlatit (nápis na hrobě), postř́brìit (stromy mrazem).

F: s prefixem od-: odvápnit (varnou konvici), odlakovat (si nehty), odnýtovat (vzpěry/ madlo/držák), odzbrojit (policejní hlídku), odzátkovat (láhev), odsedlat (koně).

G: s prefixem vy-: vybetonovat (podlahu), vyasfaltovat (silnici), vytapetovat (stěny pokoje), vyzbrojit (vojáky/objekty), vybarvit (obrázek), vysklít (okno).

\section{Slovesa (i.b) vyjadřující probíhající změnu lokace:}

Chromovat (součástky/díly), cínovat (železo), niklovat (kovové povrchy), sádrovat (nohy/ díry ve zdi), lakovat (si nehty), pudrovat (si tvár)), krémovat (si boty), bandážovat (koleno), sedlat (koně), škrobit (košile), cukrovat (koláč), razítkovat (dopisy), maskovat (si obličej), záplatovat (šaty), kroužkovat (ptactvo), roubovat (stromy), betonovat (sloupy), asfaltovat (vozovku), štěrkovat (silnici), tapetovat (stěnu), zátkovat (sudy), tmelit (praskliny).

\section{Závěr}

Problematika desubstantivních sloves jako jsou location a locatum verbs patří $\mathrm{v}$ zahraniční odborné literatuře $\mathrm{k}$ hojně diskutovaným tématům. Zde předkládaný krátký př́spěvek si kladl za cíl 1. podnítit diskusi ohledně sloves tohoto typu také v českém jazyce, 2. podat návrh, jak by tato slovesa mohla být kategorizována a uspořádána, 3. představit reprezentativní vzorek těchto sloves.

$\mathrm{Z}$ předloženého výkladu plynou následující pozorování. $\mathrm{V}$ české gramatice existují dvě možné významové struktury, které vedou $\mathrm{k}$ inkorporaci. Slovesa mohou mít: A: inkorporované jméno vyjadřující kategorii Ground. B: inkorporované jméno nesoucí kategorii Figure. S výjimkou slovesa rámovat, které povoluje obě interpretace, můžeme vždy jasně rozhodnout, která kategorie je ve slovese inkorporována. Z toho vyplývá, že slovesa s inkorporací lokativních argumentů můžeme jasně diferencovat na dvě skupiny - slovesa s inkorporací Ground (location verbs) a slovesa $\mathrm{s}$ inkorporací Figure (locatum verbs). $\mathrm{K}$ tomuto rozčlenění slouží test větné konstrukce s hyponymním objektem.

Některé prefixy jsou kompatibilní pouze s jednou tř́dou sloves. Např. prefix o- se může pojit pouze s locatum verbs (viz diskuze o slovesu ohradit). 
Slovesa jak s inkorporací Figure, tak s inkorporací Ground, můžeme vnitřně diferencovat podle toho, zda vyjadřují stav, probíhající změnu stavu, nebo provedenou změnu stavu. Stav mohou vyjádřit pouze location verbs (k rozčlenění „stavových“ sloves od sloves „změny stavu“ slouží tzv. v/do-test), probíhající změnu stavu vyjadřují neprefigovaná slovesa obou tř́d a provedenou změnu stavu prefigovaná slovesa obou tříd.

Poděkování: Příspěvek vznikl s podporou projektu GA17-10144S, PI: Pavel Caha.

\section{REFERENCE}

BAKER, Mark. 1988. Incorporation: a theory of grammatical function changing. Chicago: University of Chicago Press.

BIskup, Petr. 2015. On (Non-)Compositionality of Prefixed Verbs. In: DočEKAL, Mojmír CAHA, Pavel - Ziková, Markéta, eds., Slavic Languages in the Perspective of Formal Grammar: Proceedings of FDSL 10.5, Brno 2014. Frankfurt am Main: Peter Lang, s. 59-78.

Bleotu, Adina Camelia. 2014. Location, Locatum Verbs, and the Locative Alternation in English and Romanian. Wiener Linguistische Gazette. Special Issue 78A, s. 178-197.

CAHA, Pavel - ZıKová, Markéta. 2016. Vowel length as evidence for a distinction between free and bound prefixes in Czech. Acta Linguistica Hungarica 63(3), s. 331-377.

ClARK, Eve - ClaRK, Herbert. 1977. When nouns surface as verbs. Language 55, s. 767-811.

DE SWART, Henriëtte - ZWARTS, Joost. 2009. Less form - more meaning: Why bare singular nouns are special. In: GEBER, Dana et al., eds., Lingua. Special Issue Noun Incorporation and its Kind 119 (2), s. 280-295.

GrePL, Miroslav - KARLík, Petr. 1998. Skladba češtiny. Olomouc: Votobia.

Hale, Kenneth - Keyser, Samuel Jay. 1993. On Argument Structure and the Lexical Expression of Syntactic Relations. In: HALE, Kenneth - Keyser, Samuel Jay, eds., The View from Building 20: Essays in Linguistics in Honor of Sylvain Bromberger. Cambridge, MA: The MIT Press, s. 53-109.

HALE, Kenneth - Keyser, Samuel Jay. 2002. Prolegomenon to a Theory of Argument Srtucture. Cambridge: MIT Press.

Hirschová, Milada. 1977. Vzájemné vztahy předpon a předložek ve vazbách s prostorovým významem. Slovo a slovesnost 38(2), s. 107-111.

Kiparsky, Paul. 1997. Remarks on Denominal Verbs. In: Alsina, Alex et al., eds., Argument Structure. Stanford: CSLI, s. 1-26.

KŘEN, Michal a kol. 2015. SYN2015: reprezentativní korpus psané češtiny. Ústav Českého národního korpusu FF UK, Praha. Dostupný z: http://www.korpus.cz.

Mateau, Jaume. 2001. On the Relational Semantics of Transitive Denominal Verbs. In: EsCANDELL-VIDAL, Victoria et al., eds., Current Issues in Generative Grammar. Alcalá de Henares: Servicio de Publicaciones de la Universidad de Alcalá, pp. 143-164.

Medová, Lucie - Taraldsen, Tarald. 2007. The Czech Locative Chameleon. Nordlyd 34, S. 200-238. 
Plháková, Alena. 2004. Učebnice obecné psychologie. Praha: Academia.

Romanova, Eugenia. 2006. Constructing Perfectivity in Russian. Troms $\emptyset$. Ph.D. dissertation. University of Troms $\emptyset$.

Svenonius, Peter. 2010. Spatial P in English. In: Cinque, Guglielmo - Rizzi, Luigi, eds., Mapping Spatial PPs: The Cartography of Syntactic Structures, Vol. 6, New York: Oxford University Press, s. 127-160.

TALMY, Leonard. 2000. Figure and Ground in Language. In Toward a Cognitive Semantics. Cambridge: The MIT Press, pp. 311-344. Dostupný z: http://wings.buffalo.edu/linguistics// people/faculty/talmy/talmyweb/Volume1/chap5.pdf.

\section{Michaela Faltýnková}

Department of Czech Language

Masaryk University, Faculty of Arts

Kounicova 67/a, 602 oo Brno

Czech Republic

faltynkova@mail.muni.cz 